\title{
Editorial de Per Musi 32
}

O número 32 da revista Per Musi, qualificada com o QUALIS A1 na Área de Artes CAPES, traz 16 artigos e 2 resenhas. Sua editoração no formato XML e atribuição de números DOI (Digital Object Identification) a seus artigos, características conquistadas graças à sua indexação na base SciELO, permite agora uma grande disponibilização e recuperação internacional do conteúdo da revista.

Ralph P. Locke, em tradução de Jetro M. de Oliveira e Paulo Castagna, reflete sobre como nossas preocupações sociais e ideologias se traduzem na escolha de assuntos e repertório, e avalia seus reflexos na relação entre pesquisadores, docente e alunos da área de música e fora dela.

Eduardo Pires Rosse acompanha a fluidez e ressignificação formal dos cantos dos povos de língua maxakali, aproximando-os de um traço crítico dos espíritos amazônicos. O alinhamento diacrônico de peças dá ali lugar a um contínuo trasformacional com nódulos de adensamento localizados.

Gonçalo Dias aborda as contribuições de elementos musicais na coordenação e controle de movimentos dos esportes, aprofundando as possibilidades interdisciplinares da música com o comportamento motor, tendo em vista a aprendizagem motora e sistemas relacionados aos movimentos do corpo humano.

Gustavo Celedón Bórquez busca uma compreensão da concepção musical e da natureza política da música de John Cage por meio das reflexões filosóficas de Jacques Derrida, contrapondo a dominação europeia nas Américas ao sentimento de justiça nascido no Novo Mundo.

Em uma vertente interdisciplinar entre a musicoterapia e as neurociências Renato Tocantins Sampaio, Cybelle Maria Veiga Loureiro e Cristiano Mauro Assis Gomes exploram possibilidades de melhoria da saúde a partir de abordagens terapêuticas de ponta no tratamento de crianças e adolescentes com Transtorno do Espectro do Autismo.

Revendo as relações entre música e astronomia, Johann Hasler apresenta um "revival" da música das esferas a partir das contribuições de Johannes Kepler e da concepção heliocêntrica de Copérnico.

Alexsandro Rodrigues Meireles e Frederico Grama Cavalcante propõem uma abordagem científica para a avaliação do canto no estilo heavy metal com base no VPAS (Voice Profile Analysis Scheme), tendo no painel de avaliadores três tipos de profissionais: professores de canto, fonoaudiólogos e foneticistas.

A abordagem experimental de Michele Rosita Mantovani e Regina Antunes Teixeira dos Santos revela que, ao se depararem com obras de dificuldade mediana sob diversas restrições sensoriais (auditiva, cinestésica, visual e visual-cinestésica), pianistas recorrem mais às estratégias possibilitadas pelos efeitos de sua prática deliberada do que ao seu nível de escolaridade.

Em um artigo panorâmico, Potiguara Curione Menezes apresenta o processo de construção da identidade cultural brasileira a partir da música de concerto no século XX, estabelecendo paralelos entre objetos musicais e elementos culturais. 
A partir do conceito de usabilidade, Fausto Kothe, Clarissa Stefani Teixeira, Érico Felden Pereira e Eugenio Andrés Díaz Merino avaliam a ergonomia de espaleiras de violino e viola em músicos de orquestra.

Adentrando uma seara pouco estudada, Kássio Alves Mendes, Lívia Maria Dutra e Denise Perdigão Pereira observam as relações entre o estudo formal de música e as tendências de ganhos salariais no exercício da música no Brasil.

Líliam Barros e Marcelo Pamplona Baccino relatam sua experiência pedagógica ao inserirem a capoeira no Curso de Licenciatura em Música da Universidade Federal do Pará. Ao eleger uma das manifestações culturais, sociais e desportivas mais características do Brasil, os autores proveem diversidade e uma alternativa aos gêneros tradicionalmente aceitos na academia.

Ivan Eiji Simurra e Jônatas Manzolli apresentam a obra para orquestra de cordas Lana Tai - no dia em que nasceu uma aquarela, para a qual criam um novo ambiente de orquestração assistida por computador. Utilizando descritores de áudio para analisar sonoridades produzidas através de técnicas estendidas, os autores reportam e discutem o planejamento composicional.

Rafael Luís Garbuio e Carlos Fernando Fiorini verificam o valor musical das palavras "amor" e "morte" na obra do madrigalista Carlo Gesualdo nas suas diversas fases composicionais, que culminam em uma escrita extremamente cromática e dissonante.

Natanael Martins de Sousa e Marcos da Silva Maia apresentam uma proposta de digitação para o violão na obra de J. S. Bach, tendo em vista os parâmetros motivo, melodia polifônica, contraponto, arpejo e homogeneidade tímbrica. A partir de uma comparação entre edições de transcrições anteriores, propõem também o ajuste de ritmos e alturas de notas.

Por meio de um relato de experiência, Douglas Marques Luiz, Tania Cremonini de Araújo-Jorge e Marcus Vinicius Campus Matraca discutem as ações sociais e de saúde de um projeto de extensão de coral na cidade de Sena Madureira, Acre, entre dezembro de 2011 e dezembro de 2012.

Per Musi cobre dois livros na Seção de Resenhas - Pega na Chaleira. Primeiro, Fausto Borém apresenta o livro Como é bom poder tocar um instrumento: pianeiros na cena urbana brasileira de Robervaldo Linhares Rosa, recebedor do Prêmio Funarte de Produção Crítica em Música em 2013, e no qual traça um panorama que vai desde Chiquinha Gonzaga até Tom Jobim. Depois, Jorge Linemburg apresenta o livro Romani routes: cultural politics and Balkan music in diaspora de Carol Silverman, lançado em 2012, pela antropóloga estadunidense Carol Silverman e que trata da música romani na Macedônia e Bulgária e de seus imigrantes nos EUA, Europa Ocidental e Brasil.

Finalmente, informamos que Per Musi está disponível gratuitamente nos sites www.scielo.com.bre www.musica.ufmg.br/permusi. As versões impressas de quase todos os números da revista até o número 30 ainda podem ser compradas através do e-mail permusi@ufmg.br.

\section{Fausto Borém}

Fundador e Editor Científico de Per Musi
Eduardo Rosse e Débora Borburema

Co-Editores Científicos de Per Musi 32 